\title{
UPRAVLJANJE AKTIVNOSTIMA U FAZI DO OTVARANJA SPORTSKOG DOGAĐAJA TEHNIKOM MREŽNOG PLANIRANJA
}

\author{
Sretenka Dugalić ${ }^{1}$ \\ ${ }^{1}$ Visoka sportska i zdravstvena škola, Beograd, Srbija
}

\section{SAŽETAK}

U radu su prikazane tehnike mrežnog planiranja koje doprinose uspješnoj organizaciji sportskih i specijalnih događaja, i kao takve mogu naći svoju širu primjenu u menadžmentu u sportu. Sportski događaji uključuju često veoma velik broj učesnika (osim publike, sponzora i pripadnika medija, na Olimpijskim igrama se npr. susreće preko 10.500 učesnika). Neke sportske manifestacije traju više dana i ponavljaju se, tako da je moguće koristiti iskustva iz prošle prakse (tzv. učenje iz iskustva). Međutim, često sportski menadžeri imaju zadatak da pripremaju i organizuju sportske događaje koji će se održavati jednokratno, u relativno kratkom roku, zbog čega su specifikacije zahtijeva ograničene vremenskim, prostornim, ljudskim i vremenskim resursom.

Cilj je da se potencijalnim organizatorima sportskih događaja pruži pomoć, prenošenjem znanja i vještina, i da se istakne značaj tehnika mrežnog planiranja za menadžment u sportu. Ovo iz razloga da se poveća kompetentnost organizacionog resursa, ali i da se eventualno doprinese uštedi drugih resursa, prije svega novca, ljudi i opreme.

Primjer aplikacije tehnika mrežnog planiranja (Critical Path Method - CPM, Program Evolution and Review Technique - PERT) na sport, prikazane u radu, rezultat su iskustva autora u praktičnoj primjeni i realizaciji rješenja u oblasti upravljanja pomoću projekata jednog događaja, sa težnjom da što je više moguće, pronađu svoje mesto i u okviru sportskog menadžmenta. Na taj način se afirmiše sama oblast menadžmenta i biznisa, i posebno menadžmenta u sportu. Takođe, stvara se podloga za dalji razvoj discipline upravljanja sportskim događajima, i doprinosi nastajanju novih ideja, pomoću kojih je moguće unaprijediti sistem $\mathrm{i}$ institucije u sportu, putem obrazovnih procesa.

Ključne riječi: CPM metod, menadžment sport-skih događaja, tehnike mrežnog planiranja.

\section{UVOD}

Metod mrežnog planiranja pomoću kritičnog puta (critical path method - CPM) je tehnika upravljanja pomoću projekta koju su još davne 1950-te godine razvili Morgan R. Walker, radeći za DuPont, i E. Kelley, Jr., za Remington Rand (Kelley, 1961; Kelley i Walker, 1959). Od tada je ova tehnika našla svoju primjenu u svim oblastima privrede i neprivrede (Dugalić, 1995), pa tako i u sportu i menadžmentu u sportu (Appenzeller, 2000). To je razumljivo kada se zna da su resursi u toj oblasti veoma ograničeni, a zahtjevi za sportsko-ekonomskom efikasnošću, uslijed nagle globalizacije, izloženi sve većim očekivanjima i konkurentskom pritisku (Raič, 2006).
U radu je izložen primjer organizovanja sportske manifestacije primjenom tehnike mrežnog planiranja. Cilj je da se na bazi ovih iskustava, olakša posao organizatorima i koordinatorima sportskih događaja, na način da se uz pomoć naučnih spoznaja i kvantitativnih metoda koje stoje na raspolaganju u okviru menadžmenta, menadžmenta u sportu, i menadžmenta sportskih takmičenja, ukaže na mogućnost efektivnijeg i efikasnijeg upravljanja ljudskim, infrastrukturnim, novčanim i informatičkim resursom, u kontekstu vremenskih ograničenja (Dugalić, 2005).

Sistematskim izučavanjem organizovanja sportskih priredbi i takmičenja, pored stranih teoretičara (Aaron i Stewart, 1992; Farmer, Mulrooney i Amon, 
1996; Pitts i Stotlar, 1996), na našim prostorima bavili su se do sada brojni autori: Ljubojević (2001), Pelević (2011), Raič i Maksimović (2000), i dr. To je omogućilo jednu solidnu teorijsku bazu menadžmenta sportskih događaja, a svima njima je zajedničko to što su ove ideje našle svoju primjenu u savremenoj sportskoj praksi. Sa druge strane, takođe se pošlo od ideje da se putem empirijskih istraživanja u sportu, primenom tehnika mrežnog planiranja i drugih kvantitativnih metoda, egzaktno odrede ograničenja, faktori i pravci djelovanja u okviru ovih pojava (Bloem i Vermei, 2005; Vasiljević, 2013). Takođe, cilj je da se putem analiza potvrde pretpostavke o značaju menadžment procesa i tehnika za organizovanje događaja, i eventualno dodje do spoznaja koje bi omogućile da se dobijeni rezultati interpretiraju u svrhu potvrđivanja dobre sportske prakse, u odlučivanju kod organizovanja sportskih manifestacija, drugih, specijalnih događaja kao što su: jubileji, sajmovi, izložbe, proslave, konferencije za štampu (Van Der Wagen i Carlos, 2009), ili koriste za dalja istraživanja i primjenu u oblasti upravljanja pomoću projekata u sportu.

\section{METODE}

$\mathrm{Na}$ bazi postojećih teorijskih spoznaja iz oblasti mrežnog planiranja i CPM metoda, konstruisan je i izložen u radu jedan hipotetski model kojeg je autor rada dizajnirao na osnovu ranijih istraživanja $i$ iskustava u specijalističkom području upravljanja pomoću projekta u sportu. Osnovni cilj je da se uz pomoć ove metodologije dodje do spoznaja koje će obogatiti sportsku praksu, ali i da se afirmišu metode mrežnog planiranja u menadžmentu u sportu.

Organizovanje sportskih manifestacija se u sportskoj praksi realizuje putem etapa kao što su priprema projekta, realizacija, analiza i ocjena ostvarenih sportskih i finansijskih rezultata (HBS Pres, 2006). U fazi pripreme (konceptualizacije) analiziraju se inputi (tehnička i finansijska podrška: kapital, izvori), vrijeme, ljudski resursi, struktura trškova i prihoda i projektuju rizici (neizvršenja događaja, tj. otkazivanja, probijanja vremena, budžeta i sl.). Paralelno s tim utvrđuju se ciljevima primjereni: datum, vrijeme trajanja aktivnosti, posebni rokovi i kritični datumi. Planiranje i organizovanje događaja uključuje:

- formulisanje strategije,

- studiju izvodljivosti i donošenje odluke,

- utvrđivanje ciljeva,

- imenovanje organizacijskog komiteta i koordinatora komisija (jedinica) za razne oblasti (bezbjednost, redarska služba, mjerenje i testiranje, logistika i sl.),
- budžetiranje (finansijski plan),

- organizacionu strukturu,

- personal po sektorima (volonteri i sl.),

- detaljno planiranje,

- predstavljanje događaja uključujući pripremanje, zatvaranje i pospremanje, $i$

- vrednovanje, povratne informacije i modifikovanje za neke buduće događaje (Dugalić, 2007).

Održavanje sportskih događaja je kao što se vidi, veoma kompleksno, te se u radu žele na sistematičan način, primjenom posebne metodologije, akcentovati aktivnosti koje su ključne za uspjeh događaja. Očekivani ishod je u skladu sa postavljenim ciljem, da se primjenom kvantitativnih metoda mrežnog planiranja (CPM, PERT) ove etape i aktivnosti, računarskim tehnikama, prevedu u upravljačke modele koji mogu pomoći sportskim funkcionerima da planiraju sportski događaj, organizuju aktivnosti i provode koordinaciju tokom kasnijih faza, na rutinski način. U cilju popularizacije, pojednostavljenja i približavanja ovih tehnika za primjenu u sportu, u radu je izložen ručni (manuelni) prikaz CPM modela.

Ova tehnika mrežnog planiranja zamjenila je gantograme, jer osigurava: razumljiv pregled cijelog objekta planiranja, jednoznačno prikazuje logičke prikaze i međuzavisnost dijelova, preciznije praćenje vremena i rokova događaja, informiše pravovremeno o kritičnom vremenu najopterećenijeg dijela rada, faktora koji negativno utiču na rok završetka projekta, ometajućim faktorima koji ugrožavaju tok i završetak projekta, objektivno poredi pojedine varijante plana, kako bi se dobilo superiornije rješenje, rasterećuje planere rutinskih poslova osobito kod veoma složenih projekata, koje obavlja računar i sl. (Roel, 2011; Weiss i Gershon, 1989).

\section{REZULTATI}

Oblikovanje modela upravljanja projektom u sportu se odvija u fazama po sledećem redosledu:

- postavlja se struktura modela ili specifikacija aktivnosti neophodnih za organizovanje dogadaja;

- određuju se parametri modela koji su predodređeni subjektivnom procjenom ili procjenom parametara na osnovu podataka iz prošlosti, na bazi iskustava tokom organizovanja sličnih manifestacija (tzv. učenje iz prakse);

- ocjena modela (vrednovanje) u odnosu na teorijske i iskustvene činjenice, statističke kriterijume i testove, te praktičnu mogućnost upotrebe modela za upravljanje projektom u oblasti sportskih događaja. 
Aktivnosti iz plana upravljanja projektom u sportu odražavaju:

- jasno određenu etapu svih procesa, koji zahtjevaju vrijeme i resurs (ljudski, infrastrukturni, novčani, informatički i u vidu opreme i rekvizita);

- čekanje, ili proces upravljanja projektom koji iziskuje samo utrošak vremena, i

- zavisnost, koja ne troši ni vrijeme ni sredstva, a može biti prividna ili fiktivna.

Osnovne funkcije upravljanja projektom u sportu su: planiranje projektnih zadataka, imenovanje projektnog tima, organizovanje aktivnosti, pridruženje rokova aktivnosti projekta, kontrola tokova i resursa, upravljanje tokom projekta i ocjena projekta. Model mrežnog planiranja koji se preporučuje kod upravljanja projektima u sportu se može detaljno i tačno analizirati, na njemu se može eksperimentisati, te objasniti do kakvih rezultata dovodi neka konkretna zamisao u realizaciji projekta. To znači da je upravljanje procesom realizacije adaptibilno (može se pratiti, kontrolisati, korigovati i prilagoditi novonastaloj situaciji), što je za sportske događaje koji ponekad traju tek jedan dan, veoma primjenjivo.

Uvidom u Tabele 1 i 2, kao i Slike 1 i 2, interpretirane u narednom poglavlju, mogu se sagledati rezultati analiza koji doprinose racionalizaciji vremenskog resursa, i sa njime uzročno-posledični povezanog rasporeda ljudskog, informatičkog i novčanog resursa, što se može vidjeti i kod drugih autora (Đuričin i Lončar, 2012).

\section{DISKUSIJA}

Upravljanje projektima u sportu primjenom tehnika mrežnog planiranja nije našlo širu primjenu u sportskoj praksi. Postoje brojni problemi, poteškoće i razlozi koji ograničavaju primjenu ovih modela u sportu, prije svega neposjedovanje programskih paketa. U tu svrhu mogu da se koriste case alati ili programi, npr. Project Manager. Edukacija sportskih menadžera za upravljanje pomoću projekata u sportu kroz akreditovan kurs može podstaći na njihovu širu primjenu. Neki teoretičati kao razlog za nedovoljno prihvatanje modela u praksi navode da oni suviše pojednostavljuju stvarnost, da se situacije u sportskoj praksi mijenjaju brže od modela, da su podaci u sportskom marketingu često slabi i nekonzistentni, pa time modeli nisu pokazali superiornost u donošenju odluka.

Da bi strategija upravljanja modelom projekta u sportu bila više zastupljena, sportske organizacije treba da se osposobe za odgovarajuće tehnike vođenja, i pravilno izaberu model za željeno područje djelovanja (Chadwick, 2010). Slijedi prikaz pojednostavljenog primjera modela iz sportske prakse, apliciranog na fazu koja prethodi sportskom događaju.

\section{Procedure za realizaciju projekta}

Realizacija projekta u sportu primjenom CPM modela ima dva oslonca procedure kao što su analiza strukture i analiza vremena. Aktivnosti se započinju analizom strukture koja se sastoji od: ispostavljanja spiska aktivnosti i vremena ukupnog trajanja priprema, konstrukcije mrežnog dijagrama za sportski događaj, odnosno njegovih dijelova i kontrole u odnosu na pravila konstruisanja. Pitanja za dobijanje gantograma modela za upravljanje događajem su:

- Koje aktivnosti moraju biti završene neposredno prije?

- Koje aktivnosti moraju otpočeti neposredno poslije?

- Koje aktivnosti se mogu nezavisno paralelno odvijati?

- Da li se posmatrana aktivnost može dalje podjeliti na podaktivnosti?

Podaci za spisak aktivnosti neophodnih za odvijanje događaja se prikupljaju sistematski, a neki se otkrivaju za vrijeme same konstrukcije mrežnog dijagrama. Pravila za konstruisanje mrežnog dijagrama su da svaka aktivnost ima svoj početak i kraj iskazan kroz događaj (mora otpočeti i završiti događajem), kako slijedi:

- Naredna aktivnost nastupa tek nakon završetka prethodne aktivnosti.

- Aktivnosti koje se odvijaju paralelno, mogu nastupiti tek nakon završetka prethodne aktivnosti.

- Kada naknadna aktivnost počinje za vrijeme aktivnosti koja joj prethodi, ona se dijeli u podaktivnosti prethodnog događaja.

- Kod pojave aktivnosti sa istim početkom i završetkom, uvodi se fiktivna ili prividna aktivnost sa nultim trajanjem.

- Prividne aktivnosti koriste se u drugim slučajevima kada se ugrade uslovi i ako u jednom događaju završava i otpočinje veći broj aktivnosti koje nisu sve međusobno zavisne.

- U niz aktivnosti se može uključiti proizvoljan broj prividnih aktivnosti, a da se pri tome ne naruše konstrukcije mrežnog dijagrama, što je naročito bitno kod rastavljanja velikih dijagrama u podmreže manjeg obima. 
- Svaka aktivnost u dijagramu može se odvijati samo jednom, pa ukoliko se u fazi konstruisanja otkrije postojanje petlji, dvostrukih linija ili zatvorenih ciklusa, oni se tokom analize nelogičnosti moraju otkloniti.

Sada se na osnovi prethodnih i sledećih aktivnosti, i početnih i završnih događaja, numerišu svi događaji projekta po rastućem nizu numerisanja početnih (i) i završnih (j) događaja, pri čemu je $i<j$. Ako ovaj uslov nije ispunjen pojavljuju se sledeći problemi:

- teškoće u identifikovanju pojedinih aktivnosti i česte greške u redoslijedu pisanja brojeva,

- otežana je primjena računskih postupaka kod analize mrežnog dijagrama jer su ograničene mogućnosti uvođenja nekog reda u redoslijedu obrade podataka,

- obrada na računaru zahtijeva rastuće numerisanje mrežnog dijagrama, i

- teško se otkrivaju zatvoreni ciklusi (petlje) koje treba otkloniti iz mrežnog dijagrama.

Kod projekta sa velikim brojem aktivnosti ovi se problemi teško mogu otkloniti, pa je pridržavanje navedenih pravila veoma bitno. Za označavanje se koriste simboli: $\mathrm{i}, \mathrm{j}=$ događaji ili čvorovi, $(\mathrm{i}, \mathrm{j})=$ aktivnosti po redosledu, $t_{i j}=$ trajanje aktivnosti $u$ vremenskim jedinicama. Kod planiranja i realizacije sportskog događaja, sve aktivnosti su procesom deparmentalizacije grupisane u zadatke posebno oformljenih komisija, odbora ili sektora (za bezbjednost, hospitalizaciju učesnika, cermonijalni dio, logistiku, praćenje sportskih događaja, saradnju sa medijima, medicinsku podršku, redarsku službu...). Na taj način se raspored aktivnosti po grupisanim poslovima prikazuje u okviru jedinstvene vremenske linije, kako je to prikazano u Tabeli 1.

\section{Analiza vremena (početaka i završetaka] potrebnog za realizaciju aktivnosti projekata}

$\mathrm{Na}$ bazi aktivnosti opisanih u tabeli broj 1, može se konstruisati dijagram toka aktivnosti, u skladu sa vremenskom linijom (Slika 1).

Kada se izvrši analiza strukture, autor projekta pristupa analizi vremena ili završetka jedne ili više aktivnosti ili cijelog projekta. Početni događaj je

TABELA 1

Lista aktivnosti za dijagram toka sportskog projekta.

Oznaka aktivnosti

Definisanje misije, ciljeva i naziva manifestacije, marketing istraživanja o sličnim, ranije održanim manifestacijama, prikupljanje podataka o strukturi programa, upoznavanje sa regulativom (zakoni,

1. propisi sportskih asocijacija), aktivnostima koje prethode svečanom otvaranju, podaci o potencijalnim učesnicima, procjena posjećenosti, spisak potencijalnih sponzora, plan prikupljanja sredstava. Izrada idejnog koncepta;.

Izrada studije iquvodjivosti i podnošenje nadležnim tijelima ukoliko se to zahtjeva, sa svim neophodnim

2. podacima (naziv manifestacije, organizator, mjesto i datum održavanja, ciljevi organizovanja, aktiv-

nosti, očekivanja u pogledu sportskih rezultata i broja učesnika, program takmičenja, okvirna finansijska sredstva neophodna za projekat).

Donošenje odluke o organizovanju i početku sportske manifestacije, o kandidaturi ako je to neophodno, pod-

3. nošenje plana aktivnosti sportske manifestacije i izrada elaborata, tj. kompletne, neophodne dokumentacije, obavještavanje nadležnih sportskih tijela i komisija, pribavljanje neophodnih saglasnosti.

Procjena posé́enosti: broj učesnika i posjetioca, određivanje visine kotizacije, broj uključenih sponzora

4. i aproksimativna ukupna vrijednost, određivanje raspona cijena ulaznica, očekivani odziv publike i ukupna vrijednost, broj, vrijednost i rapored koncesija.

5. Organizovanje strukture menadžmenta: imenovanje tijela ili odbora za koordinaciju (organizacioni tim), odredivanje nivoa koordinacije i broja radnih tijela i komisija.

6. Imenovanje ostalih ǔ́esnika u organizacionoj strukturi, menadžera i izvršioca, plan broja volontera i redarske službe;.

7. Izrada troškovnika po svim kategorijama: mjestu nastanka, rokovima i izvršiocima.

8. Prognoz̧a prihoda i planiranje buď̌eta, usklađivanje sa troškovnikom.

9 Irrada programa licenciranja, $i$ kontakti sa medijima u cilju podjele troškova, prodaja prava prenosa.

10 Planiranje realizacije sportskog događaja: plan vođenja, rukovođenja i kontrolisanja aktivnosti tokom sportske manifestacije, za sve sekvence koje propisuju zakon, pravilnici ili dobra upravljačka praksa.

Irrada finansijskog plana (plana prihoda i rashoda), direknih i indirektnih prihoda i troškova, po

11 kategorijama, tarife, cjenovnici i bonifikacije za razne kategorije učesnika, sportiste, publiku, sponzorski pul, medije, zakupce štandova... Strategije diferenciranja s obzirom na obim, vrijeme i način plaćanja

3


Plan nabavki: opreme, rekvizita, opremanja prostora, ozvučenja, napajanja električnom energijom,

12. informativnim materijalom, kancelarijskim materijalom, sredstvima za higijenu, medicinskim mate-

rijalom, porudžbine hrane i pića za osvježenje i koktele, propagandnog materijala, plan idejnog rješenja i realizacije plaketa, medalja i zahvalnica i sl..

13. Plan informisanja učesnika i javnosti, putevi i načini plasmana informacija.

5

14. Istraživanje stavova javnosti, opremanje objekata na izabranoj lokaciji neophodnom opremom i rekvizitima, plan logistike, planiranje smještajnih kapaciteta i transfera ukoliko za to ima potrebe.

Plan kontakta i načina komunikacije sa svim prijavljenim učesnicima i zainteresiranim stranama (pripa-

15. dnici organa unutrašnjih poslova, sponzori, mediji, dobavljači, javnost, akreditacije učesnika i novinara).

16. Planski pokazatelji: procjena efekata manifestacije.

Imenovanje radnih tijela $i$ komisija, izrada kalendara aktivnosti i detaljne vremenske linije po pojedinim

17. sekvencama aktivnosti, dijagram toka aktivnosti takmičarskog dijela, izrada dnevnog plana praćenja i metoda procjene realizacije aktivnosti.

18. Plan izvrř́enja po vrsti aktivnosti, broju, plan, broj i raspored volontera po komisijama, plan raspodjele resursa neophodnog za realizaciju aktivnosti, u skladu sa troškovnikom.

Plan marketinga, plan promocije, ekonomske propagande i drugih vidova promocije, plan podsticanja

19. prodaje u koordinaciji sa sponzorima i zakupcima, plan aktivnosti za promotere i medije, izrada štampanih, audio i audio-vizuelnih materijala i saopštenja za javnost.

20. Sastavljanje i potpisivanje ugovora za sve vrste proizvoda, opreme, rekvizita, potrošnog materijala (snabdjevanje) i prethodno preciziranih i zahtjevanih usluga, prema troškovniku.

Plan aktivnosti sponzora uključenih u projekat, plan medijskih aktivnosti, poželjno u vidu posebnog

21. mrežnog plana promotivnih aktivnosti sa detaljnim opisom elemenata promotivnog miksa (propa-
ganda, podsticanje prodaje, promoteri, odnosi s javnošću), vrijeme trajanja aktivnosti po medijima, uz preciziran budžet, sadržaj, način i sredstvo komunikacije.

22. Grafička, likovna, vizuelna (maskote, logo, plakati, katalozi), audio, audio-vizuelna rjě̌enja, lektura sadržaja, izrada prototipa i konačne verzije promotivnog materijala.

23. Provjera kandidata za rad na projektu, selekcija i imenovanje izvršioca, sklapanje ugovora, njihova obuka i uključivanje u projekat.

Provjera svih planova (toka odvijanja sportskih aktivnosti, bezbjednosti, kretanja posetioca, sportista i VIP, medicinskih planova i načina djelovanja, svih vidova i dinamike kontrole sportista: mjerenje

24. težine, medicinski pregledi, doping kontrola). Ocjena realizovanih aktivnosti od strane organizacionog tima, donošenje odluke o načinu koordinacije tokom održavanje događaja, ustanovljavanje sistema kompenzacije za izvršioce (način nagrađivanja i penali za kašnjenje, neažurnost ili primjedbe na rad pojedinih izvršioca i slično).

25. Irrada edukativnih materijala, sertifikata, ID kartica, uniformi, dekora i dostavljanje učesnicima.

Odštampan promotivni materijal, audio i audio-vizuelni, magnetni i dr. medijski zapisi dostavljeni spon-

26. zorima, medijskim kućama i javnosti prema medija planu u cilju emitovanja i isporuke u vidna polja potencijalnih posjetioca-publike i javnosti.

Angažovanje personala u skladu sa ugovorom o radu i drugim vidovima radnog angažovanja. Provjera

27. plana aktivnosti čišćenja i održavanja prije, tokom i poslije završetka događaja. Angažovanje izvještača i voditelja kod ceremonijalnog dijela.

Finalizacija projekta, potvrđeni spiskovi učesnika i medijskih pokrovitelja, isporučen propagandni

28. materijal, angažovan personal, provjera: realizacije ugovora, snadbjevanja opremom, rekvizitima potrošnim materijalom, odobrenja nadležnih ustanova (organa unutrašnjeg reda, sportskih strukovnih asocijacija), slanje pozivnica gostima za učešče na ceremoniji otvaranja sportske manifestacije.

Seminar za volontere, provjera: tehnike, mjernih uređaja, ozvučenja, napajanja električnom energijom, koordinacije sa spoljašnjim izvršiocima (organi reda, medicinske ekipe, novinari, izveštači, kamer-

29 mani, delegati, sudije, sponzori, volonteri). Inspekcija terena za igru i sastavljanje zapisnika o tome. Uvid u gotov materijal, medalje, plakete, nagrade, audio zapisi himne, sastavljanje protokola za ceremonije proglašenja: otvaranja manifestacije, pobjednika i čin zatvaranja manifestacije.

Opremanje dijela predvidenog za ceremonije dekorom i dr. neophodnim sredstvima (cvijeće, specijalni efekti i sl.). Proba svečanog otvaranja, dodjele medalja i zatvaranja. Organizovanje koktela za sve, veče prije početka manifestacije kako bi se pružila mogućnost sponzorima da ukažu gostoprimstvo, podstaklo pisanje medija u prisustvu sportista i zainteresovali potencijalni posjetioci. Plan registracije učesnika i rasporeda takmičenja. Svečano otvaranje ceremonijalnog karaktera sa pratećim oficijelnim sportskim, zabavnim i komercijalnim programima.

(1)


stanje u kojem neka aktivnost može otpočeti, a završni događaj - stanje njenog završetka. Početni i završni događaj projekta koji odražavaju njegov početak i završetak su posebni slučajevi, pri čemu početni događaj nema prethodnih, a završni događaj slijedećih aktivnosti.

Analiza vremena (u odnosu na strukturu) se razlikuje prema izabranom modelu mrežnog planiranja. Kod transformacije modela u matematički, uočavaju se razlike između ovog i PERT modela. Kod CPM modela se javlja deterministički, a kod PERT stohastički model, koji uvodi u račun nesigurnost vremenske procjene trajanja pojedinih aktivnosti. U domaćoj literaturi se može naći primjer upravljanja sportskim projektom primjenom PERT modela (Dugalić 2007), pomoću kojeg se mogu pratiti troškovi upravljanja sportskim događajem i provoditi izmjene (skraćenje ili produženje) uz istovremeno pridruženje resursa (uštede ili probijanje budžeta). Vremena trajanja aktivnosti kod oba modela služe za izračunavanje ostalih vrijednosti u analizi vremena. Broj zadatih vremena opredeljuje izbor između CPM ili PERT modela jer PERT uvažava i najvjerovatnije vrijeme (kao razliku između pesimističkog i optimističkog vremena). Analiza vremena kod CPM modela (koji je prikazan u radu) se sastoji u: određivanju vremena trajanja aktivnosti, progresivnog i retrogradnog izračunavanja vremena realizacije projekta i pronalaženja kritičnog puta kao i vremenskih rezervi.

Progresivno izračunavanje vremena polazi od najranijeg završnog događaja projekta. Računa se:

- Najraniji početak svake aktivnosti $\left(t_{i}^{0}\right)$ i jednak je najranijem vremenu u kojem je postignut događaj, i

- Najraniji završetak aktivnosti (i-j), označava se kao toj i jednak je najranijem vremenu u kojem je postignut događaj j, a dobije se zbrajanjem vremena trajanja te aktivnosti s vremenom $t^{0}$.

Kada je određen najraniji završetak aktivnosti koje imaju n kao završni događaj (najraniji završetak projekta $t_{n}^{0}$ ), pristupa se izračunavanju najkasnijih početaka i najkasnijih završetaka bilo koje aktivnosti (i-j), i te se vrijednosti unose u mrežni dijagram. Ovo je retrogradno računanje vremena, a polazi od završnog događaja i kreće se ka početnom događaju. Pri tome vrijedi da je: najranije vrijeme nastupanja završnog događaja projekta ujedno i najkraće vrijeme potrebno za njegovu realizaciju, a najranije vrijeme nastupanja završnog događaja projekta ujedno i najkasnije vrijeme nastupanja tog događaja.

Progresivno i retrogradno računanje vremena daje vrijednosti koje služe za izračunavanje kritičnog puta i vremenskih rezervi. Kritični put su niz aktivnosti u sportskom projektu, međusobno povezanih, koje se protežu između početnog i završnog događaja mrežnog dijagrama, a imaju zbirno najduže vrijeme trajanja. Svi događaji koji leže na kritičnom putu imaju jednako najranije i najkasnije vrijeme nastupanja, odnosno vrijednost vremenskih rezervi nula (0). Ove aktivnosti na kritičnom putu su na mrežnom dijagramu podvučene dvostrukim linijama, a o završetku tih aktivnosti ovisi i završetak plana sportske manifestacije.

Popunjavanjem tabele za mrežni dijagram navode se sve relevantne veličine. Slijede podaci za izračunavanje najranijih završetaka pojedinih aktivnosti progresivnim postupkom prema (Dobrenić, 1987):

$$
\mathrm{t}_{\mathrm{j}}^{(0)}=\mathrm{t}_{\mathrm{i}}^{(0)}+\mathrm{t}_{\mathrm{ij}}
$$

Ukoliko u događaj i ulazi više puteva, najraniji početak bilo koje aktivnosti koja ima j kao početni događaj, računa se prema:

$$
\mathrm{t}_{\mathrm{j}}^{0}=\max _{\mathrm{i}}\left\{\mathrm{t}_{\mathrm{i}}^{0}+\mathrm{t}_{\mathrm{ij}}\right\} ; \quad \mathrm{t}_{\mathrm{i}}^{0}=0
$$

Kada se projekat ne može završiti u planiranom roku, potrebno je izvršiti korekcije u mrežnom dijagramu skraćenjem roka trajanja aktivnosti upravljačkim procesom, na kritičnim putevima dok se ne postigne:

$$
\mathrm{t}_{\mathrm{n}}^{0}=\mathrm{T}_{\mathrm{p}}=\mathrm{t}_{\mathrm{n}}{ }^{1}
$$

gde $t_{n}{ }^{1}$ označava najkasniji završetak projekta.

Najkasniji početak svih aktivnosti i-j izračunava se oduzimanjem vremena trajanja aktivnosti od najkasnijeg završetka aktivnosti prema:

$$
\mathrm{t}_{\mathrm{i}}^{1}=\mathrm{t}_{\mathrm{j}}^{1}-\mathrm{t}_{\mathrm{ij}}
$$

Ukoliko iz početnog događaja i izlazi više aktivnosti, najkasnije vrijeme postizanja tog događaja računa se prema:

$$
\mathrm{t}_{\mathrm{i}}^{1}=\min _{\mathrm{j}}\left\{\mathrm{t}_{\mathrm{j}}{ }^{1}+\mathrm{t}_{\mathrm{ij}}\right\} ; \quad \mathrm{t}_{\mathrm{n}}{ }^{1}=\mathrm{t}_{\mathrm{n}}{ }^{0}
$$

Ukoliko je za neku aktivnost $(i-j), t_{j}{ }^{1}-t_{i}^{0}-t_{i j}=0$, tada se ta aktivnost naziva kritična aktivnost. Kod aktivnosti kod kojih je vrijeme trajanja aktivnosti veće od normiranog vremena trajanja aktivnosti, tj. veća od 0 , postoji izvjesna vremenska rezerva.

Tada se pristupa izračunavanju vremenskih rezervi kako bi se otkrili subkritični putevi koji imaju vrlo malu vremensku rezervu i mogu lako postati kritični. Nekritične aktivnosti raspolažu sa izvjesnom rezervom vremena (ukupnom, slobodnom, nezavisnom) u odnosu na posmatranu aktivnost prema aktivnostima koje joj neposredno prethode ili slijede iza posmatrane aktivnosti (Tabela 2).

Aktivnosti na kritičnom putu idu preko događaja koji imaju jednaka najranija i najkasnija vremena: 1 , 


\section{SLIKA 1}

Dijagram toka aktivnosti sportskog projekta, skica mrežnog plana.

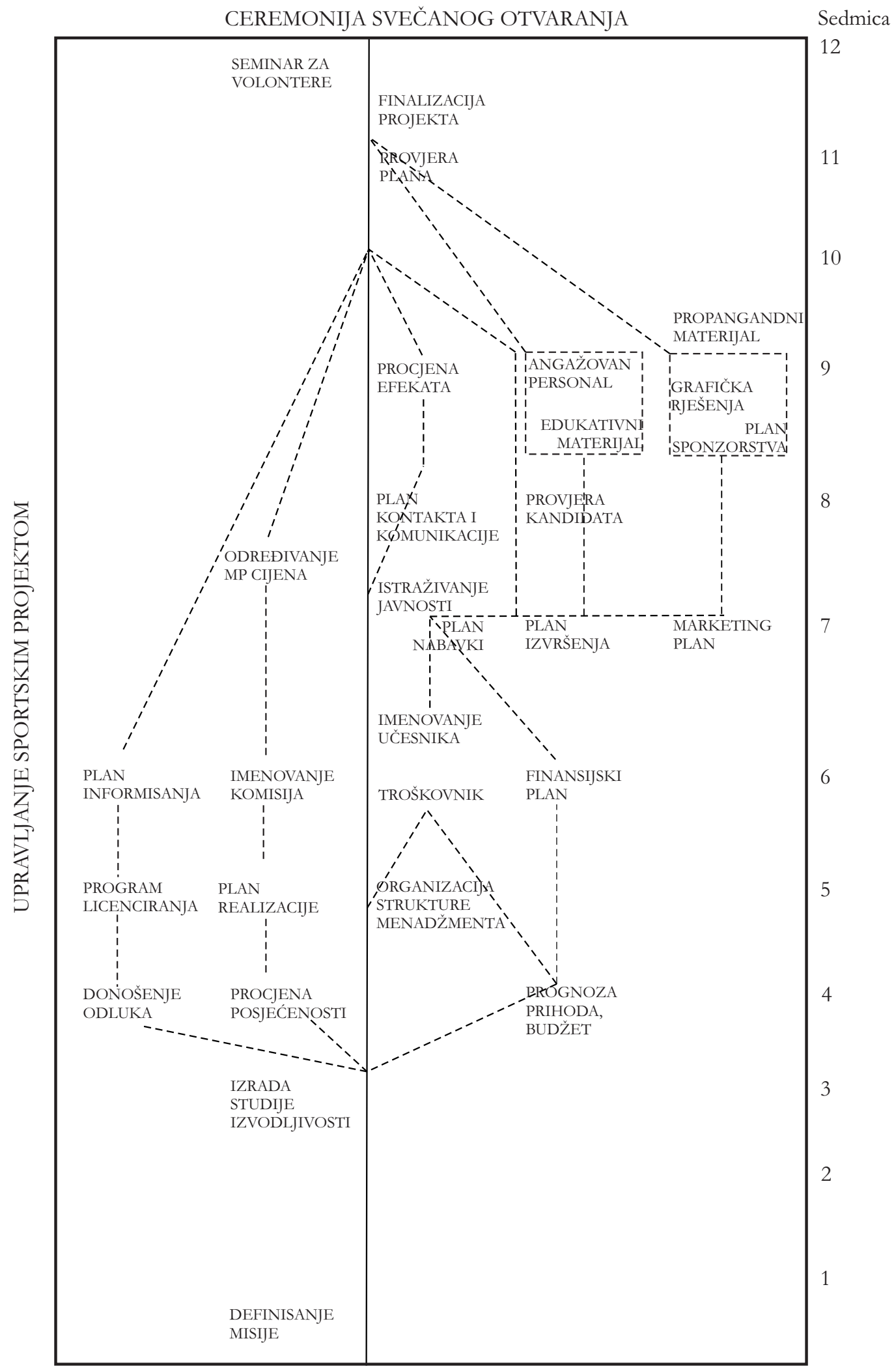

2, 5, 6, 14, 16, 24, 28 i 30. Izračunate vrijednosti se unose u lijevu poziciju odgovarajućeg događaja u mrežnom dijagramu, a polazi se od pretpostavke da je najranije vrijeme završetka projekta $\mathrm{t}_{\mathrm{n} 1}{ }^{0}=\mathrm{t}_{30}{ }^{0}=90$ dana, ujedno i najkasnije vrijeme završetka projekta tj. $\mathrm{t}_{\mathrm{n}}{ }^{1}=\mathrm{t}_{30}{ }^{1}=90$ dana. To su 3. i 4. kolona iz Tabele 2, pri čemu se koriste dodatne formule ako u događaj j ulazi više aktivnosti. 
Retrogradnim postupkom sada se izračunaju Izračunate vremenske rezerve koje imaju negativan najkasniji počeci pojedinih aktivnosti prema $t_{i}^{1}=t_{j}^{1}$

- $t_{\text {ij }}$, (6), i te se vrijednosti unose u 5. i 6. kolonu Tabele 2:

Izračunavanju vremenskih rezervi pristupa se kako bi se otkrili subkritički putevi, koji imaju vrlo malu vremensku rezervu i mogu lako da postanu kritični.

$$
\begin{array}{rlrl}
\mathrm{t}_{1}{ }^{(0)}=0, \text { followed by: } \mathrm{t}_{2}{ }^{0} & & \mathrm{t}_{5}{ }^{0}=30+10=40 \\
& =0+30=30 & & \mathrm{t}_{8}^{0}=30+7=37 \\
\mathrm{t}_{4}{ }^{0} & =30+3=33 & \mathrm{t}_{6}^{0}=40+4=44 \\
\mathrm{t}_{3}{ }^{0} & =30+5=35 & &
\end{array}
$$

\begin{tabular}{|c|c|c|c|c|c|c|c|c|c|}
\hline Događaj & \multirow{2}{*}{ Trajanje } & \multicolumn{2}{|c|}{ Najraniji } & \multicolumn{2}{|c|}{ Najkasniji } & \multicolumn{3}{|c|}{ Vremenske rezerve } & \\
\hline Početni Završni & & Poč. & Zavr. & Poč. & Zavr. & Ukupno & Slobodne & Nezavisne & \\
\hline 1 & 2 & 3 & 4 & 5 & 6 & 7 & 8 & 9 & \\
\hline \multirow{2}{*}{$i-j$} & & & & & & $(6-3-2)$ & $(4-3-2)$ & $(4-5-2)$ & \\
\hline & tij & $t^{0}$ & $t_{i}^{0}$ & $t_{i}^{1}$ & $\mathrm{t}^{1}$ & $\mathrm{~s}_{\mathrm{ji}}^{\mathrm{t}}$ & $\mathrm{s}_{\mathrm{ij}}^{\mathrm{s}}$ & $\mathrm{s}^{\mathrm{n}}{ }_{\mathrm{ij}}$ & \\
\hline $1-2$ & 30 & 0 & 30 & 0 & 30 & 0 & 0 & 0 & $\mathrm{~K}$ \\
\hline $2-8$ & 7 & 30 & 37 & 30 & 48 & 11 & 0 & 0 & \\
\hline $2-3$ & 5 & 30 & 35 & 30 & 60 & 25 & 0 & 0 & \\
\hline $2-4$ & 3 & 30 & 33 & 30 & 68 & 35 & 0 & 0 & \\
\hline $2-5$ & $10^{\prime}$ & 30 & 40 & 30 & 40 & 0 & 0 & 0 & K \\
\hline $5-6$ & 4 & 40 & 44 & 40 & 44 & 0 & 0 & 0 & $\mathrm{~K}$ \\
\hline $5-7$ & 7 & 40 & 47 & 40 & 52 & 5 & $(-3), 0$ & $(-3), 0$ & \\
\hline $8-11$ & 5 & 37 & 48 & 48 & 53 & 11 & 6 & $(-5), 0$ & \\
\hline $3-9$ & 3 & 35 & 38 & 60 & 63 & 25 & 0 & $(-25), 0$ & \\
\hline $4-10$ & 3 & 33 & 36 & 68 & 71 & 35 & 0 & $(-35), 0$ & \\
\hline $7-11$ & 1 & 47 & 48 & 52 & 53 & 8 & 8 & $(-5), 0$ & \\
\hline $11-12$ & 2 & 48 & 50 & 53 & 60 & 10 & 0 & 1 & \\
\hline $9-13$ & 5 & 38 & 43 & 55 & 68 & 25 & 0 & $(-17), 0$ & \\
\hline $6-14$ & 15 & 44 & 59 & 44 & 59 & 0 & 0 & 0 & $\mathrm{~K}$ \\
\hline 14-15 & 7 & 59 & 66 & 59 & 74 & 8 & 0 & 0 & \\
\hline $16-24$ & 15 & 59 & 74 & 59 & 74 & 0 & 0 & 0 & K \\
\hline $17-24$ & 3 & 36 & 74 & 71 & 74 & 35 & 35 & 0 & \\
\hline $11-18$ & 2 & 48 & 50 & 53 & 67 & 17 & 0 & 1 & \\
\hline 11-19 & 5 & 48 & 53 & 53 & 58 & 5 & 0 & $(-5), 0$ & \\
\hline $13-20$ & 14 & 43 & 57 & 60 & 82 & 25 & 0 & $(-17), 0$ & \\
\hline $21-26$ & 5 & 53 & 63 & 63 & 68 & 10 & 5 & $(-5), 0$ & \\
\hline $22-26$ & 10 & 53 & 63 & 58 & 68 & 5 & 0 & $(-5), 0$ & \\
\hline $23-27$ & 10 & 50 & 60 & 67 & 77 & 17 & 0 & $(-17), 0$ & \\
\hline $12-24$ & 14 & 50 & 74 & 60 & 74 & 10 & 10 & 0 & \\
\hline $18-25$ & 7 & 50 & 57 & 67 & 77 & 20 & 0 & $(-17), 0$ & \\
\hline $26-28$ & 14 & 63 & 82 & 68 & 82 & 5 & 5 & 0 & \\
\hline $27-28$ & 5 & 60 & 82 & 77 & 82 & 17 & 17 & 0 & \\
\hline $24-28$ & 8 & 74 & 82 & 74 & 82 & 0 & 0 & 0 & $\mathrm{~K}$ \\
\hline $28-29$ & 7 & 82 & 90 & 82 & 90 & 1 & 0 & 0 & \\
\hline $28-30$ & 8 & 82 & 90 & 82 & 90 & 0 & 0 & 0 & K \\
\hline
\end{tabular}

TABELA 2

$V$ remensko trajanje, vremenske ręerve $i$ iæračunavanje kritičkog puta.

Legend: Poč. - Početak; Zavr. - Završetak; K - Kritični put. 


$$
\begin{array}{lc}
\mathrm{t}_{7}{ }^{0}=40+7=47 & 66+0=66 \\
\mathrm{t}_{11}{ }^{0}=37+5=42=48 \max _{\mathrm{i}} & 59+15=74 \\
47+1=48 & \mathrm{t}_{25}{ }^{0}=50+7=57 \\
\mathrm{t}_{9}{ }^{0}=35+3=38 & \mathrm{t}_{26}{ }^{0}=\max _{\mathrm{i}} 53+5=58=63 \\
\mathrm{t}_{10}{ }^{0}=33+3=36 & 53+10=63 \\
\mathrm{t}_{12}{ }^{0}=48+2=50 & \mathrm{t}_{27}{ }^{0}=\max _{\mathrm{i}} 57+0=57=60 \\
\mathrm{t}_{13}{ }^{0}=38+5=43 & 50+10=60 \\
\mathrm{t}^{14}{ }_{0}=44+15=59 & 60+5=65 \\
\mathrm{t}_{15}{ }^{0}=\mathrm{max} 59+7=66 & \mathrm{t}_{28}{ }^{0}=\max _{\mathrm{i}} 63+14=77=82 \\
36+3=39 & 74+8=82 \\
57+0=57 & \mathrm{t}_{29}{ }^{0}=82+7=89 \\
\mathrm{t}_{16}{ }^{0}=59+0=59 & \mathrm{t}_{30}{ }^{0}=\max _{\mathrm{i}} 89+0=89=90 \\
\mathrm{t}_{17}{ }^{0}=36+0=36 & 82+8=90
\end{array}
$$

vremenski predznak, odnose se isključivo na nezavisnu vremensku rezervu i imaju vrednost 0 jer važi:

$$
\mathrm{s}_{\mathrm{ij}}{ }^{\mathrm{n}}=\max \left\{0, \mathrm{t}_{\mathrm{j}}^{0}-\mathrm{t}_{\mathrm{i}}^{0}-\mathrm{t}_{\mathrm{ij}}\right\}
$$

Aktivnosti koje nisu na kritičnom putu, raspolažu s rezervom vremena u relaciji prema aktivnostima koje neposredno prethode ili slijede iza posmatrane aktivnosti. Postoje: ukupna, slobodna i nezavisna vremenska rezerva. Vrijednost vremenskih rezervi se u tabeli računa oduzimanjem vrijednosti pojedinih kolona.

Ukupna vremenska rezerva (kolona 7 u Tabeli 2), računa se prema:

$$
\mathrm{s}_{\mathrm{ij}}^{\mathrm{t}}=\mathrm{t}_{\mathrm{j}}^{1}-\mathrm{t}_{\mathrm{i}}^{0}-\mathrm{t}_{\mathrm{ij}}
$$

za svaku aktivnost, npr. za 2-8 iznosi 11 dana i predstavlja razliku između maksimalno dozvoljenog vremena koje stoji na raspolaganju za izvođenje aktivnosti i vremena njenog trajanja. To znači da se vrijeme trajanja ove aktivnosti može pomaknuti za 11

$$
\begin{aligned}
& \mathrm{t}_{22}{ }^{1}=90-8=82 \quad \mathrm{t}_{9}{ }^{1}=59-15=44 \\
& \mathrm{t}_{21}{ }^{1}=82-8=74 \quad \mathrm{t}_{8}{ }^{1}=60-5=55 \\
& \mathrm{t}_{20}{ }^{1}=82-5=77 \\
& \mathrm{t}_{19}{ }^{1}=82-14=68 \\
& \mathrm{t}_{18}{ }^{1}=77-10=67 \\
& \mathrm{t}_{17}{ }^{1}=74-14=60 \\
& \mathrm{t}_{16}{ }^{1}=\min _{\mathrm{j}} 77-7=67 \\
& 67-0 \\
& \mathrm{t}_{15}{ }^{1}=68-10=58 \\
& \mathrm{t}_{14}{ }^{1}=68-15=63 \\
& \mathrm{t}_{13}{ }^{1}=60=74-10 \\
& \mathrm{t}_{12}{ }^{1}=74-3=71 \\
& \mathrm{t}_{11}{ }^{1}=74-15=59 \\
& \mathrm{t}_{7}{ }^{1}=\min _{\mathrm{j}} 60-2=58 \\
& 67-2=65=53 \\
& 58-5=53 \\
& \mathrm{t}_{6}{ }^{1}=53-1=52 \\
& \mathrm{t}_{5}{ }^{1}=71-3=68 \\
& \mathrm{t}_{4}{ }^{1}=55-3=52 \\
& \mathrm{t}_{3}{ }^{1}=53-5=48 \\
& \mathrm{t}_{2}{ }^{1}=\min _{\mathrm{j}} 44-4=40 \\
& 52-7=45 \\
& \mathrm{t}_{1}{ }^{1}=\min _{\mathrm{j}} 52-5=47 \\
& 68-3=65=30 \\
& \mathrm{t}_{10}{ }^{1}=\min _{\mathrm{j}} 74-7=67=59 \\
& 40-10=30 \\
& 48-7=41 \\
& \mathrm{t}_{0}{ }^{1}=30-30=0
\end{aligned}
$$

dana od njenog najranijeg početka, a da pri tome rok završetka projekta ne bude ugrožen. Ako se ova vremenska rezerva optereti u cjelosti, poklapaju se najraniji i najkasniji završetak pa od ovog mjesta može nastati novi kritički put, jer su sve vremenske rezerve sledećih aktivnosti takođe iscrpljene.

Slobodna vremenska rezerva nastaje u slučaju kada u događaj j ulaze dvije ili više aktivnosti, a igra važnu ulogu kod skraćenja ili preoblikovanja mrežnog dijagrama. Računa se prema:

$$
\mathrm{s}_{\mathrm{ij}}^{\mathrm{s}}=\mathrm{t}_{\mathrm{j}}^{0}-\mathrm{t}_{\mathrm{i}}^{0}-\mathrm{t}_{\mathrm{ij}}
$$

Kod aktivnosti 17-24 ona iznosi čak 35 dana, a to znači da se za toliko može produžiti ili pomaknuti trajanje ove aktivnosti, a da se i dalje zadrže najraniji počeci kod narednih aktivnosti.

Nezavisna vremenska rezerva postoji kod aktivnosti 11-12 i 11-18 u trajanju od 1 dana i znači da se za toliko može produžiti vrijeme trajanja te aktivnosti, odnosno pomaknuti rok najranijeg početka aktivnosti. Ovo pomjeranje neće uticati na vremenske relacije drugih aktivnosti u mrežnom dijagramu ako se izvrši pomak od samo jednog dana.

Uslovna vremenska rezerva u ovom primjeru nije izračunavana (odnosi se na događaje mreže za razliku od ostalih vremenskih rezervi koje se odnose na aktivnosti). Ukoliko se vrši, obračun radi se po formuli:

$$
\mathrm{s}_{\mathrm{j}}^{\mathrm{u}}=\mathrm{t}_{\mathrm{j}}^{1}-\mathrm{t}_{1}^{0}
$$

Ona definiše kritičnost događaja i služi kao mjera subkritičnosti događaja.

Pozicija vremenskih vrednosti u mrežnom dijagramu su prikazane kao na Slici 2.

Izgled konačnog mrežnog plana upravljanja projektom u sportu prikazan je u Slici 3.

\section{ZAKLJUČAK}

Model mrežnog planiranja u sportu, ukoliko se implementira, može značajno doprinijeti rješenju organizacionih problema, kod planiranja složenih sportskih i specijalnih događaja. Kada se želi konkurisati za dobijanje šampionata, potrebno je proći određene procedure, sa brojnim zahtevima koji se odnose na pravila sportskih asocijacija, potrebe sastavljanja troškovnika i upravljačkih zahtijeva, kako bi se kandidatura kod sportskih događaja realizovala na način da organizator ostvari pozitivne ekonomske i druge efekte.

U radu su iznesene neke od kvantitativnih teorija (modeli mrežnog planiranja) sa praktičkim objašnjenjem modela na jednom primjeru iz prakse, čime se nas- 


\section{SLIKA 2}

Unošenje vremenskih vrednosti $u$ događaje mrežnog dijagrama.

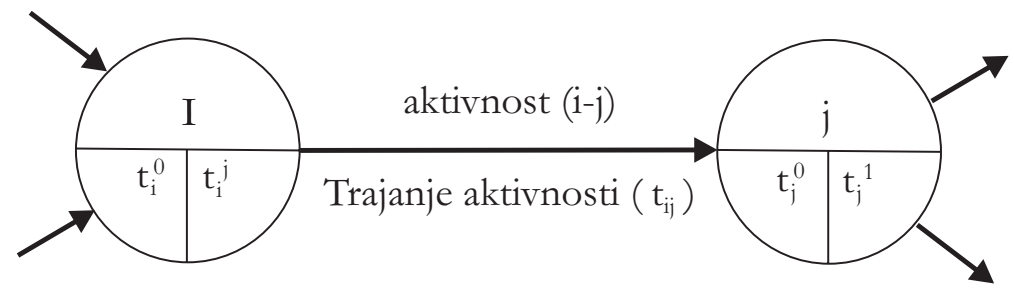

\section{SLIKA 3}

Mrě̌ni plan upravljanja projektima u sportu.

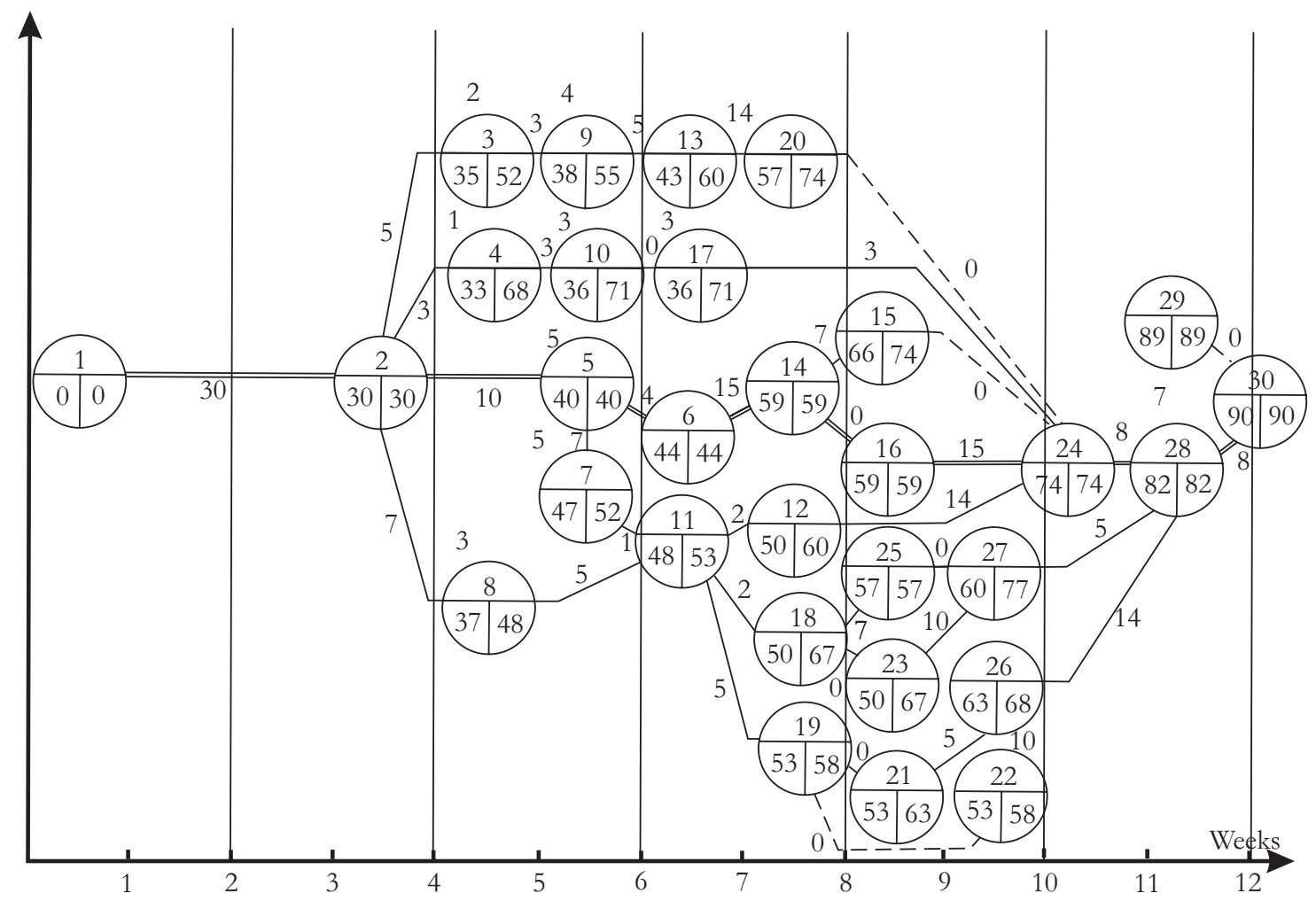

Legenda: Puna linija - Tok redovnih aktivnosti; Isprekidana linija - Veza između aktivnosti koje imaju nultu ili negativnu nezavisnu rezervu); Dupla linija - Putanja aktivnosti koje leže na kritičnom putu.

toji afirmisati njihova primjena u sportu. Takođe se želi podstaći na motivisanost za izgradnju programske podrške putem koje se njihova primjena u sportu podiže na viši nivo, i samim tim postavljaju zahtjevi pred menadžment tim organizatora sportskih projekata da ove tehnike i metode unapređuje u skladu sa potrebama i očekivanim nivoom tehnološkog i informacionog razvoja.

\section{LITERATURA}

Aaron, S., \& Stewart B. (1992). Sports management.

Melbourne, AU: Allen \& Unwin Pty Ltd.

PMCid: PMC1737143
Appenzeller, H. L. (2000). Successful sport management. 2nd ed. Durham, NC: Carolina Academic Press.

Bloem, M., \& Vermei, A. (2005). The olympic road to performance improvement. Performance Improvement, 44(6), 7-13. doi: 10.1002/ pfi. 4140440604

Chadwick, J. S. (2010). Sportski menadžment [The business of sport mangement]. Zagreb, HR: Mate.

Dobrenić, S. (1987). Operativno istra živanje [Operational research]. Varaždin, HR: Fakultet organizacije i informatike.

Dugalić, S. (1995). Lansiranje novog proizvodnog asortimana [The launch of the new product assortment]. Plasman i trǐiste, 2, 21-31. 
Dugalić, S. (2005). Finansijski i marketinški aspekti strategija u sportu [Financial and marketing aspects of the strategy in sport]. Belgrade, RS: Viša škola za sportske trenere.

Dugalić, S. (2007). Menadæ̌ment sportskih objekata [Management of sports facilities]. Belgrade, RS: Visoka škola za sport.

Đuričin, D., \& Lončar, D. (2012). Menadžment pomoću projekata [Management by projects]. Belgrade, RS: Centar za izdavačku delatnost Ekonomskog fakulteta u Beogradu.

Farmer J. P., Mulrooney L. A., \& Amon R. Jr. (1996). Sport facility planning and management. Morgantown, WV: Fitness Information Technology, Inc.

Harvard Business School Press. (2006). Menadžment projekta [Project management]. Belgrade, RS: Data status.

Kelley, J. (1961). Critical path planning and scheduling: Mathematical basis. Operations Research, 9(3), 1091-1105. doi: 10.1287/ opre.9.3.296

Kelley, J., \& Morgan, W. (1959). Critical-Path Planning and Scheduling. Proceedings of Eastern Joint Computer Conference (pp. 160-173). Boston, MA, December 1959.

Ljubojević, Č. (2001). Menaď̆ment i marketing u sportu [Management and marketing in sport]. Belgrade, RS: ̌̌elnid,
Pelević B. (2011). Menadžment sportskih takmičenja [Management of sports events]. Belgrade, RS: Visoka sportska i zdravstvena škola.

Pitts B. G, \& Stotlar, D. (1996). Fundamentals of sport marketing. Morgantown, WV: Fitness Information Technology, Inc.

Raič, A. (2006). Sportski menadžment kao profesija i kao nauka [Sports management as a profession and as a science]. In Đ. Nićin (Ed.), 2nd International conference $»$ Management in sport« (pp. 17-24). Belgrade, RS: Fakultet za menadžment u sportu Univerziteta »Braća Karić«.

Raič, A., \& Maksimović, N. (2000). Sportski menadžment [Sports management]. Novi Sad, RS: Fakultet fizičke kulture.

Roel, G. (2011). Project management. Groningen, NL: Noordhoff Uitgevers B.V

Van Der Wagen, L., \& Carlos, B. R. (2009). Upravljanje dogadanjima [Event management]. Beograd, RS: Mate d.o.o.

Vasiljević, D. (2013). Material requirements planning in manufacturing of sport industry equipment. In D. Životić and V. Šiljak (Eds.), Proceedings of 8th International conference »Management in sport» (pp. 324-330). Belgrade, RS: Fakultet za menadžment u sportu Alfa univerziteta.

Weiss, H. J., \& Gershon, M. E. (1989). Production and operations management. Boston, MA: Allyn and Bacon

Primljeno: 19. aprila 2013. godine Izmjene primljene: 29. septembra 2013. godine

Odobreno: 17. oktobra 2013. godine

Korespondencija: Dr Sretenka Dugalić Visoka sportska i zdravstvena škola

Toše Jovanovića 11 11000 Beograd Srbija

Telefon: 00381112380537 E-mail: sretenkadugalic@yahoo.com 